\title{
Pharmacological and Other Interventions for Head and Neck Cancer Pain: a Systematic Review
}

\author{
Patrick B. Trotter ${ }^{1}$, Lindsey A. Norton ${ }^{1}$, Ann S. Loo ${ }^{1}$, Jonathan I. Munn ${ }^{1}$, Elena Voge ${ }^{1,2}$, \\ Kim W. Ah-See ${ }^{3}$, Tatiana V. Macfarlane ${ }^{1}$ \\ ${ }^{1}$ School of Medicine and Dentistry, University of Aberdeen, Aberdeen, United Kingdom. \\ ${ }^{2}$ University of Bremen, Bremen, Germany. \\ ${ }^{3}$ Department of Otolaryngology, Aberdeen Royal Infirmary, Aberdeen, United Kingdom.
}

\author{
Corresponding Author: \\ Tatiana Macfarlane \\ University of Aberdeen Dental School \\ Cornhill Road, Foresterhill \\ Aberdeen, AB25 2ZR \\ United Kingdom \\ Phone: $(+44)(0) 1224551585$ \\ Fax: $(+44)(0) 1224554761$ \\ E-mail: Tatiana.Macfarlane@abdn.ac.uk
}

\begin{abstract}
Objectives: Pain is a common complication in head and neck cancer. The aim of this paper is to evaluate the evidence from randomised control trials investigating pharmacological and non-pharmacological methods of pain management in head and neck cancer.

Material and Methods: Medline, Embase and the Cochrane library databases were searched. Squamous cell carcinomas of the head and neck excluding nasopharyngeal and salivary gland cancers were included. The limits were "human" and "randomised clinical trials". A quality assessment was carried out.

Results: 13 studies were included with a total of 644 participants. The primary outcome for most of these papers was pain control post-treatment. Levels of bias varied between the studies. Majority (12 out of the 13 studies) reported intervention to be superior to the control or standard therapy in pain management. Only $46 \%$ of the studies were carried out on an intention to treat basis. Two studies reported high dropout rates, with one at $66 \%$.

Conclusions: There is insufficient evidence from randomised clinical trials to suggest an optimal pharmacological intervention for head and neck cancer pain post-treatment. Further high quality randomised clinical trials should be conducted to develop an optimal management strategy for head and neck cancer pain.
\end{abstract}

Keywords: head and neck neoplasms; pain, postoperative; analgesics, opioid; pain measurement; systematic review.

Accepted for publication: 20 December 2012.

To cite this article:

Trotter PB, Norton LA, Loo AS, Munn JI, Voge E, Ah-See KW, Macfarlane TV. Pharmacological and Other Interventions for Head and Neck Cancer Pain: a Systematic Review.

URL: http://www.ejomr.org/JOMR/archives/2012/4/e1/v3n4e1ht.pdf

doi: $10.5037 /$ jomr.2012.3401 


\section{INTRODUCTION}

Head and neck cancer (HNC) is defined as "cancer that arises in the head or neck region (the nasal cavity, sinuses, lips, mouth, salivary glands, throat, or larynx)" [1]. The main histological type is squamous cell carcinoma (SCC) [2]. HNC is more common in men. In 2009 there were over 6000 new HNC diagnoses in the United Kingdom and the incidence is increasing [3] . A geographical variation exists for HNC [4]. Within the United Kingdom, the highest incidence is in Scotland, North of England and Northern Ireland [3] . Major risk factors for $\mathrm{HNC}$ are tobacco consumption, heavy alcohol drinking, poor nutrition, specifically low fruit and vegetable consumption and Human Papillomavirus (HPV) [5-7].

Treatment depends upon the type, staging of the tumour and assessment of co-morbidities [8-9]. The main treatment options are surgery, radiotherapy, chemotherapy and brachytherapy. Combination therapy has been proven more successful than single modality [10].The mainstay is surgery and adjuvant radiotherapy [11]. Surgery often results in tissue loss; hence, the use of prosthetics and grafts is necessary to provide a good functional and cosmetic outcome [12-13].

Pain is defined as "an unpleasant sensation ranging from mild discomfort to agonized distress, associated with real or potential tissue damage" [14]. Scales to measure pain rely on patients reflecting on previous experiences and are therefore unreliable but provide an easy and quick, if subjective, method to gauge pain severity [15] Examples of pain scales regularly used include: Visual Analogue Scale (VAS), Numerical Rating Scale (NRS), Wong Baker Faces scale, COMFORT scale and Visual Numerical Scale (VNS) [16-20].

Cancer pain is divided into three categories: tumour induced pain, iatrogenic pain and incidental pain [21]. Tumour induced pain is caused by tissue damage; a consequence of rapid tumour growth, tumour pressure, metastasis or the development of a neuroma. Chemotherapy and radiotherapy result in iatrogenic pain. Incidental pain is caused by any condition present simultaneously with cancer [22]

Pain is a common problem presenting in patients with HNC [23]. A systematic review showed high levels of pain prevalence in HNC patients, particularly before treatment [24]. One study reported pain prevalence being as high as $86 \%$ [25].

Pain location and severity in HNC can vary enormously from dysphagia, to pain in the face, neck and ears $[2,26]$. Those who have received surgery for their HNC can also develop pain in the shoulder and arm $[23,27]$. The WHO has developed a 3-tiered ladder for pain control [28], and this guideline is the mainstay for HNC pain management. It states that "if pain occurs, there should be prompt oral administration of drugs in the following order: nonopioids; then, as necessary, mild opioids; then strong opioids such as morphine, until the patient is free of pain. To calm fears and anxiety, adjuvants should be used. To maintain freedom from pain, drugs should be given "by the clock", that is every 3 - 6 hours, rather than "on demand". Surgical intervention on appropriate nerves may provide further pain relief if drugs are not wholly effective" [28]. WHO guidelines for pain relief were validated for cancer pain [29], and specifically for HNC pain. It was shown that the use of analgesic and adjuvant drugs along $\mathrm{WHO}$ guidelines to treat pain in $\mathrm{HNC}$ is highly effective and relatively safe [30]. However the pain ladder may have limitations in the context of longterm survival [31]. Review of studies which evaluated WHO analgesic ladder in patients with cancer pain showed that there is insufficient evidence for the effectiveness of the WHO guidelines because of lack of the randomised clinical trials [32].

The aim of this paper is to evaluate the evidence from randomised control trials investigating pharmacological and non-pharmacological methods of pain management in head and neck cancer.

\section{MATERIAL AND METHODS Types of studies}

This review was conducted following PRISMAstatement for reporting systematic reviews [33]. All randomised clinical trials (RCTs) investigating interventions for HNC pain, post-treatment were included.

\section{Types of participants}

Human adults (over the age of 18) with primary HNC or metastases to the head and neck were included.

\section{Stage of Cancers}

All stages of $\mathrm{HNC}$ were included in this paper.

\section{Types of Publications}

The following were excluded: Letters, Editorials, Postgraduate thesis, case reports and qualitative studies.

\section{Outcome measures}

Pain measured using pain scales such as VAS, NRS, and VNS [16-20]. Studies, which used patient benefit 
including pain control as an outcome, were also included in this paper.

\section{Literature search methods for identification of studies (Figures 1, 2)}

The literature search aimed to identify RCTs conducted after 1946. The OVID search engine was used to identify relevant studies. The limits used for each search were: RCT and Human. Exclusion criteria for studies included: paper subject was mucositis or xerostomia, nasopharyngeal and salivary gland cancers, or outcome was not assessing pain management.

MEDLINE (1946 - present) was checked using the search terms "head and neck neoplasms" or exp facial neoplasms or exp mouth neoplasms or exp otorhinolaryngologic neoplasms were combined with Facial Pain or Acute Pain or exp Pain or Pain, Postoperative or Chronic Pain or Pain Management OR "Anesthesia and Analgesia" or exp Analgesia or Analgesia, Patient-Controlled or Analgesia, Epidural exp anti-inflammatory agents, non-steroidal or exp analgesics, opioid exp Morphine.

Embase classic and Embase (1947 - present) search strategy was carried out to resemble the MEDLINE search strategy as closely as possible. The search terms: head and neck neoplasms/exp face tumor or exp "head and neck tumor" or exp eyelid tumor or exp face cancer exp mouth tumor or exp mouth cancer or exp pharynx tumor/or exp tongue tumor or "head and neck tumor" or jaw tumor or lip tumor or neck tumor were combined with exp analgesia or exp patient controlled analgesia or exp postoperative analgesia exp jaw pain or exp neck pain or exp cancer pain or exp neuropathic pain or exp chronic pain or exp face pain or exp postoperative pain or exp pain assessment or exp pain or exp nonsteroid antiinflammatory agent or anti-inflammatory agent exp morphine exp opiate.

References of chosen studies were checked as well as the Cochrane database of systematic reviews [34].

Each search was independently carried out by two authors and all abstracts identified were screened by two or more authors. Full reports were obtained for all studies that were deemed eligible for inclusion in this paper. One paper by Yagi et al. [35] was not available in full text, however, the abstract has been analysed as far as possible.

\section{Data extraction}

The following information was extracted: First Author, Year of publication, Study location, Participant information (number, age, gender), Inclusion and Exclusion criteria, Intervention, Comparison group, Duration/follow-up, Method of outcome measurement, dropout rate and results.

\section{Quality assessment}

All of the included studies were also subjected to

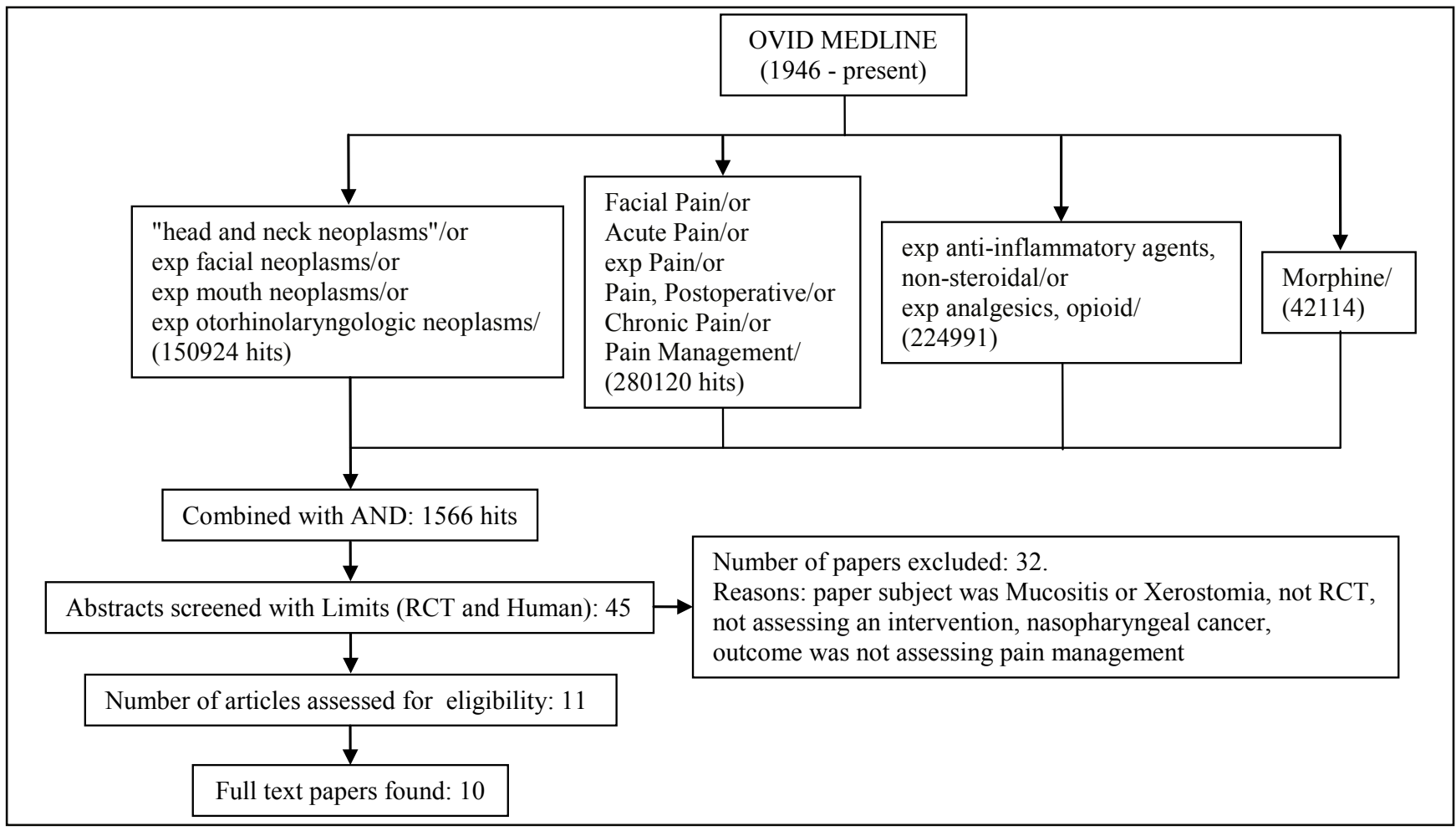

Figure 1. MEDLINE search. 


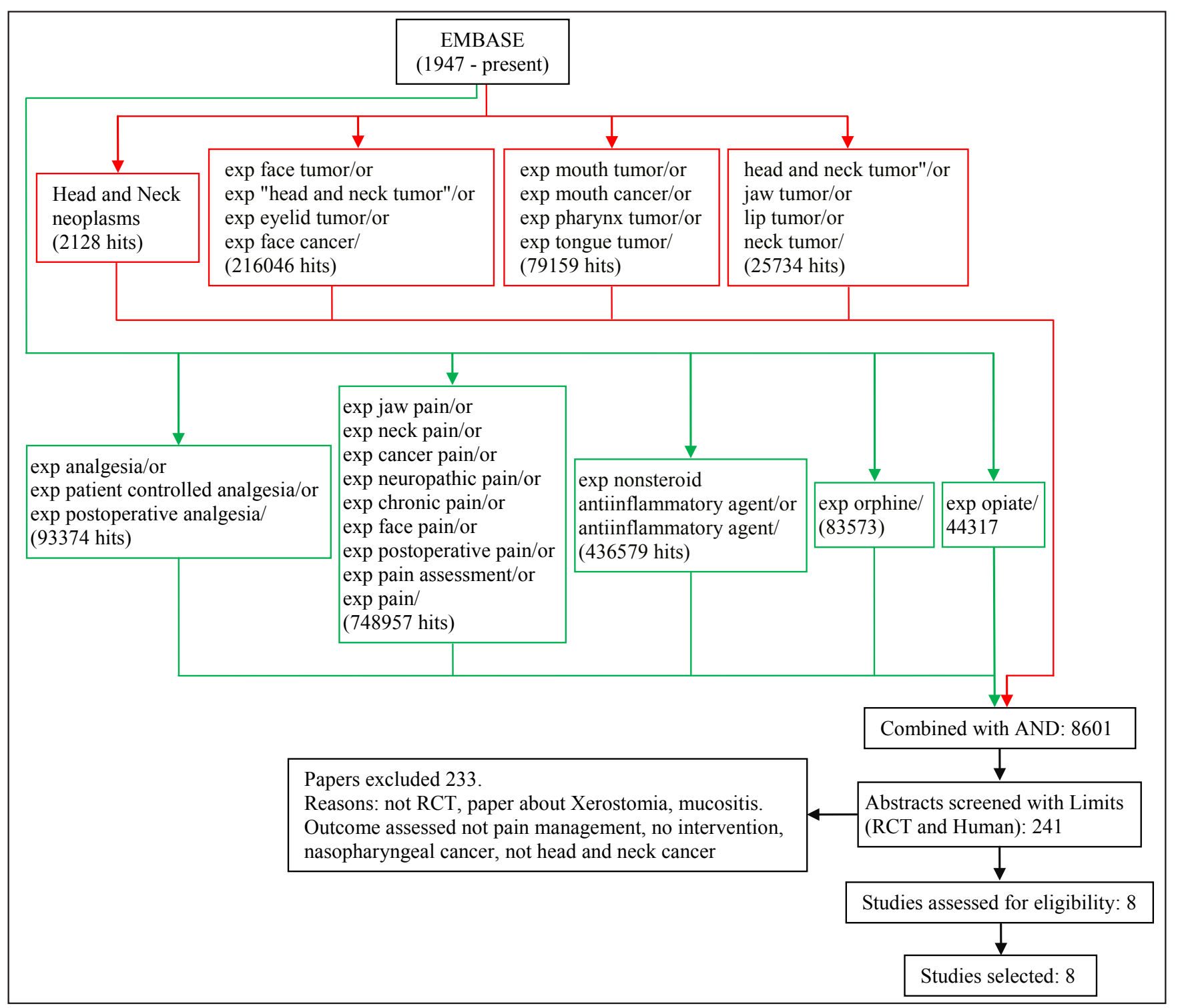

Figure 2. EMBASE search.

a quality assessment in the form of a critical appraisal. This was based on a modified Ian Crombie method from his book the pocket guide to critical appraisal [36]. This critical appraisal had 19 items (Author, Randomised, Blinding, Clear aims stated, Justified sample size, Baseline characteristics, Administration discrepancies, Untoward events, Unusual characteristics of sample, Intention to treat basis, Adequacy of basic data, numbers calculated adequately, description of statistical methods, Side effects, Null finding interpretation, Important effects overlooked, Comparisons with previous literature and Implications for clinical practise).

\section{Bias Summary (Figure 3)}

The Cochrane collaboration bias summary illustrates seven areas of potential bias and was used to assess the quality of studies and identify papers with intrinsic flaws in method and design [37].

\section{RESULTS}

Total of 13 studies were included in this review (Table 1 and Table 2).

The majority of studies (76.9\%) explored the possible impact of pharmacological interventions on pain caused by HNC [35,38-46]. Three studies $(23.1 \%)$ examined the effect of other interventions such as progressive resistance exercise training (PRET) [27,47] or acupuncture [48]. The sample size of the studies ranged from 20 to 92 , with a median of 50. Werner et al. [45] reported the highest drop out rate in the intervention group $(56.1 \%)$ and in the placebo group $(82.9 \%)$. The lowest drop out rate was stated with $0 \%[\underline{39-40}, \underline{44}, \underline{46}]$. Five out of 13 studies were conducted in European countries $[39-42,46]$ and 4 in the United States and Canada [27,38,47-48], two in India [43-44] and one further publication enrolled patients from Europe and Israel [ㄴ5]. 


\begin{tabular}{|c|c|c|c|c|c|c|c|c|}
\hline$?$ & $\begin{array}{l}=\text { present } \\
=\text { absent } \\
=\text { unknown/not specified }\end{array}$ & 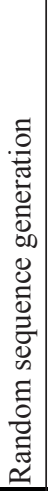 & 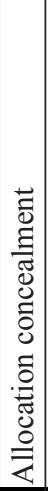 & 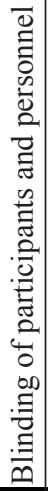 & 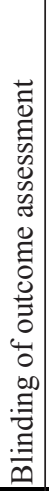 & 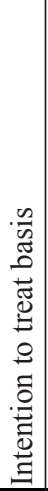 & 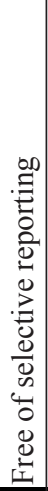 & 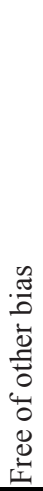 \\
\hline & Castro et al. 2003 [료 $]$ & + & $\odot$ & $\odot$ & - & $\ominus$ & $\odot$ & $\odot$ \\
\hline & Georgiou et al. $2000[\underline{\underline{39}}]$ & $\odot$ & + & 단 & 단 & - & $\odot$ & + \\
\hline & Jovic et al. 2008 [우] & $\odot$ & $\odot$ & $\theta$ & - & $\odot$ & 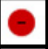 & $\odot$ \\
\hline & McNeely et al. 2004 [47] & $\odot$ & $?$ & 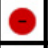 & ? & $\odot$ & $\odot$ & † \\
\hline & McNeely et al. 2008 [27] & $\odot$ & $\odot$ & $\odot$ & ? & $\odot$ & $\odot$ & † \\
\hline & Pfister et al. 2010 [48] & $\odot$ & $\odot$ & $\odot$ & ? & ○ & $\odot$ & $\odot$ \\
\hline & Plantevin et al. 2007 [41] & † & $\odot$ & $\odot$ & $\odot$ & $\theta$ & $\odot$ & $\odot$ \\
\hline & Roussier et al. 2006 [늘 & + & + & + & + & $\theta$ & + & $\Theta$ \\
\hline & Saxena et al.1994 [푸 $]$ & $\odot$ & $\odot$ & + & $\theta$ & $\theta$ & + & + \\
\hline & Singhal et al. 2006 [44] & 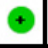 & $\odot$ & $\theta$ & $\odot$ & $\odot$ & $\odot$ & + \\
\hline & Werner et al. 2002 [도] & 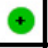 & $\odot$ & + & $\Theta$ & $\theta$ & $\theta$ & ? \\
\hline & Wittekindt et al. 2006 [46] & $?$ & $\Theta$ & + & + & + & + & + \\
\hline & Yagi et al. 1997 [35] & $\odot$ & $?$ & $?$ & $?$ & $?$ & $?$ & $?$ \\
\hline
\end{tabular}

Figure 3. Bias summary.

Studies by Werner et al. [45] and Castro et al. [38] show a higher percentage of patient benefit among the intratumoral cisplatin/epinephrine injectable gel (CDDP/epi gel) group 19\% and 34\%, compared to the placebo group $9 \%$ and $12 \%$ respectively. These benefits included pain control, however this difference did not reach statistical significance in either study $(\mathrm{P}=0.24$ and $\mathrm{P}=0.25$ ). Roussier et al. [42] showed that mean VAS pain score at two and six hours after surgery was lower in the epidural Fentanyl group compared to the intravenous (IV) Fentanyl group. Singhal et al. [44] demonstrated that epidural Morphine provided better analgesia than IV Morphine with $\mathrm{P}<0.05$. Plantevin et al. [41] investigated the effect of MNB on post-surgical pain, concluding that it was effective in reducing initial postoperative pain 24 hours after surgery. The trial comparing Piroxicam and Acetylsalicylic acid (ASA) conducted by Saxena et al. [43] showed that Piroxicam was a viable alternative to ASA as the first step in the WHO pain ladder for treatment of HNC pain. Wittekindt et al. [46] showed that more patients experienced pain relief in the low dose Botox A group compared to the high dose group. However, there was no significant statistical change in VAS score at baseline or 28 days. Jovic et al. [41] reported that Ketoprofen was superior to Metamizole in controlling post-surgical pain, however this was only statistically significant on day three of treatment $(\mathrm{P}<0.05)$. Cervical epidural Morphine was shown to provide longer lasting analgesia compared to thoracic epidural by Georgiou et al. [39] while also requiring smaller doses. McNeely et al. [47] reported in 2004 that patients in the PRET group had an overall decrease in pain score of $17 \%$ compared to an increase of $1.7 \%$ in the control group. In a follow-up study in 2008 the authors reported that overall pain score had a significant larger decrease in the PRET group compared to the current standardized therapeutic exercise protocol (TP) group after adjustment of demographic and medical variables $(P=0.005)$ [27]. The treatment of pain after neck dissection with acupuncture and usual care was shown to be superior to usual care alone such as analgesics and anti-inflammatory drugs $(\mathrm{P}<0.001)$ by Pfister et al. [48].

\section{Quality assessment}

In Table $3 \mathrm{~A}$ the methodological quality of the studies was assessed containing randomization, blinding and sample. Furthermore possible bias and the statistical methods used in each study are described in Table 3B. Table 3C shows important information about any side effects of treatment and gives practice implication for each intervention.

\section{Castro et al. 2003 [38]}

This double blinded RCT was investigating intratumoural CDDP/epi gel in advanced HNC. The study had a sample size of 87 patients and low dropout rate of 1 participant make the results more reliable. However the low drop out rate could be due to the fact that the treatment plan was broadly defined. In the blinded phase in which CDDP/epi gel or placebo gel were administered patients could receive a 6 weekly treatments in an 8 -week period or less. Only $23 \%$ of patients who received CDDP/epi gel completed six treatments and none of the patients who were treated with placebo gel. Also patients got the possibility to cross over in the open label phase after the failure of three treatments in which they received active drug. There was an intentionally increased number of participants in the active group (ratio of 2:1). The reasons for doing this were not stated and could introduce bias. The study had a wide exclusion criterion, which could introduce bias and mean the results cannot be applied to the wider population.

\section{Georgiou et al. 2000 [39]}

This RCT had a small sample size of $29 \mathrm{HNC}$ patients. Pain control, with either cervical epidural morphine administration or thoracic epidural morphine technique, 
was investigated. Neither a method of randomisation was stated, nor were patients, personnel or assessors blinded. A limitation of this paper is that the administration of analgesia in the community was carried out by a health care professional whose skill set is not adequately described, hence allowing for the possibility of bias A large number of side effects occurred in this study. More cases of nausea, vomiting and constipation were reported in the intervention group.

\section{Jovic et al. 2008 [40]}

This single blinded RCT investigated whether Ketoprofen was superior to Metamizole for relieving postoperative pain following $\mathrm{HNC}$ operations. The study had a sample size of 60 patients. The method of randomisation was not stated in the paper leading to a question of bias and the statistical methods used were not described. This trial had no drop out and the aims were clearly stated. The follow-up was stated as being over 3 to 5 days, however, the results only show up to the third day.

\section{McNeely et al. 2004 [47]}

This RCT studied the efficacy of PRET in the control of pain after neck dissection surgery as a result of HNC. Subjects within the control arm performed active and passive range of motion (ROM) exercises, which constituted the standard care. This pilot study had a very small sample size $(n=20)$ reducing the power to draw accurate conclusions. The groups were similar in most respects, except there were more advanced tumour stages included in the exercise group. Analysis was not carried out on an intention to treat basis, which may skew results towards a positive benefit in the exercise group. A major discrepancy included significant variation in the time between surgery and the initiation of the exercise program. Further the study shows an insufficient control of confounders.

\section{McNeely et al. 2008 [27]}

This study had a small sample of 52 participants. The planned sample size was 60 participants, so the study was underpowered. Pain and shoulder dysfunction were assessed with the Shoulder Pain and Disability Index (SPADI) questionnaire [49], which is both valid and reliable method of assessment. Limitations in this study were large variations in time from surgery to intervention and a higher number of subjects with cancer stage 4 in the TP group (72\%) than in the PRET group (44\%).

\section{Pfister et al. 2010 [48]}

A RCT investigating the efficacy of acupuncture in cancer patients with pain after neck dissection. 58 patients participated in this trial which compared acupuncture with physical therapy and analgesics to physical therapies and analgesics alone. 28 subjects were assigned to the acupuncture arm and 30 patients took part as controls. Due to the small sample size, although justified, and the differences between the two treatment groups (e.g. higher proportion of women in acupuncture arm) this trial provides limited evidence for the use of acupuncture. The participant's awareness of the treatment group can potentially influence pain self-assessment.

\section{Plantevin et al. 2007 [41]}

This trial was randomized using sealed coded envelopes and double blinded by separating and sedating the patients who received either mandibular nerve block (MNB) or a control subcutaneous (s.c.) injection of normal saline. Both groups also received general anaesthesia (GA). There was a 7\% drop out rate from the initial 42 patients, falling short of the calculated justified sample size of 21 subjects in each group. There was no intention to treat. Subjects were required to understand the use of patient controlled analgesia (PCA), excluding patients who might have learning or communication difficulties. The nerve block efficacy could not be evaluated in order to maintain blinding.

\section{Roussier et al. 2006 [42]}

This double blind RCT comparing the efficacy of IV versus epidural Fentanyl in the treatment of acute postsurgical pain in HNC patients. The study suffered a drop out rate of $9 \%$, which does not adversely affect conclusions but was not carried out on an intention to treat basis. The patient sample was restricted by all patients being long-time smokers with associated bronchitis. They were required to adequately understand the PCA system before surgery commenced. In clinical practise the epidural technique was found to provide better pain control, however significant risks of the epidural catheterisation resulted in an unfavourable risk benefit ratio.

\section{Saxena et al.1994 [43]}

In this trial the randomisation process was not specified, but the blinding process was described as double blind. Double dummy technique where patients in both groups received both the test drug and placebo helped maintain blinding. There was a high dropout rate of $28 \%$, with no mention of a justified sample size, therefore the results may not have adequate power to detect a difference between groups. Both groups were comparable at baseline; however the treatment doses given to the groups were not comparable. A limitation of this study was a short follow-up of only 4 days as ASA and Piroxicam might differ in the short term compared to 
the long term use.

\section{Singhal et al. 2006 [44]}

This RCT investigated epidural Morphine analgesia compared to IV Morphine for oral surgery with pectoralis major myocutaneous flap (PMMF) reconstruction. The aims were clearly stated and a justified sample size of 60 was calculated and met. 30 patients enrolled in the epidural- and in the IV- morphine group, respectively. A blind observer carried out the pain intensity in each participant using the VAS pain scale.

\section{Werner et al. 2002 [45]}

This double blind RCT with clearly stated aims investigated injected epinephrine gel in the local control of cancer pain related to tumour regression. The study was larger than others in the field with 92 participants and met the calculated justified sample size initially; however there was a large dropout $(56.1 \% \mathrm{CDDP} /$ epi gel group; $82.9 \%$ placebo gel group) across the study period resulting in reduced reliability. Pain relief due to the intervention was measured using a patient questionnaire. Results may have been skewed by the variable volume of gel injected, which was anything up to $10 \mathrm{ml}$ depending on patient and tumour tolerance. Only the most problematic tumours were included. There were a large number of side effects recorded restricting its clinical use to only the most severe cases and in whom all other interventions have been ineffective.

\section{Wittekindt et al. 2006 [46]}

This dose- finding study compared the effect of low dose and high dose BtxA in patients with chronic neuropathic pain post neck dissection for HNC. With 23 patients the sample size is small; however it met the calculated sample size. Baseline data of patients was not adequately presented, but the authors claim that the two groups were comparable at baseline. There was no placebo group in this study because the effectiveness of BtxA in post surgery pain treatment of patients with $\mathrm{HNC}$ has been reported in prior studies.

\section{Yagi et al. 1997 [35]}

A full critical appraisal was not conducted for the paper by Yagi et al. as the full text was not available.

\section{Random sequence generation}

All of the studies reviewed used random sequence generation with the exception of Wittekindt et al. [46]. In this paper the authors used a member of the nursing staff to randomly allocate patients with no mention of the method of randomisation being used in this process.

\section{Allocation concealment}

McNeely et al. [47] and the abstract of the study by Yagi et al. [35] did not mention a method for allocation concealment. In using members of staff to allocate patients Wittekindt et al. [46] may have introduced bias by the lack of concealment.

\section{Blinding of participants and personnel}

5 out of 13 papers did not carry out staff blinding, patient

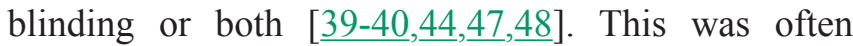
because the method of administration did not allow patient blinding, and the preparation and implementation prevented staff blinding. Again Yagi et al. [35] did not provide enough information in the available abstract to draw any conclusions about blinding.

\section{Blinding of outcome assessment}

8 of 13 studies did not have blinded outcome assessment $[\underline{27}, \underline{38-41}, \underline{43}, \underline{45}, \underline{47}, \underline{48}]$.

\section{Intention to treat basis}

Only 5 of the 13 studies discussed intention to treat basis $[27,40,44,46-47]$.

\section{Free of selective reporting}

Jovic et al. [40] stopped reporting results after 3 days of follow-up where benefit was seen in the intervention group despite the planned follow period being up to 5 days.

\section{Free of other bias}

Three papers were sponsored by the pharmaceutical companies producing the intervention treatment $[\underline{38}, \underline{42}, \underline{45}]$.

\section{DISCUSSION}

This systematic review investigated the efficacies of various pain management therapies for $\mathrm{HNC}$ patients. There are few RCTs using identical treatments, multiple therapies were reviewed. As pain is unique to the individual, a diverse spectrum of treatments is advantageous when deciding upon analgesia.

There was a wide range of dates and locations of publication for all papers analysed. No study was carried out in the United Kingdom, making any conclusion drawn less applicable to a UK based population. 
One full text paper by Yagi et al. [35] could not be found. Its omission results in the information being incomplete with possible adverse effects on conclusions.

Two trials compared IV to epidural administration of medications. Roussier et al. [42] investigated Fentanyl, an opiod analgesic that is between 80 to 100 times more potent than Morphine [50]. They concluded that the epidural administration of Fentanyl was only marginally more effective at reducing pain. Singhal et al. [44] drew similar conclusions when comparing the epidural administration of morphine; however, there are significant risks associated with epidural catheter insertion [51]. Thus the papers concluded that risk outweighed benefit.

Roussier et al. [42] involved participants that had undergone laryngeal surgery for cancer with tracheotomy. The PCA-Epid group showed better pain relief 2 and 6 hours after surgery, however, the use of the cervical epidural administration of Fentanyl could have severe complications and does incur a long recovery period with functional difficulties. Consequently postoperative IV analgesia would be safer and more practical than cervical epidural opioid administration [52]. Singhal et al. [44] involved participants that were undergoing a radical procedure for oral cancer surgery with PMMF reconstruction. This procedure involves two surgical sites, which give rise to greater postoperative pain than in the study done by Roussier et al. [42]. Hence comparisons between the two trials need to be carefully interpreted, but the conclusion that epidural administration of an analgesic in the short term is more effective than IV administration can be drawn. More complex pain management therapies can be employed such as nerve blocks as demonstrated by the study by Plantevin et al. [41]. The study investigated the efficacy of using Ropivacaine, a local anaesthetic, to block the mandibular nerve. The nerve block reduced the PCA morphine consumption. The authors concluded that it was effective at reducing postoperative pain; however, appropriate anatomical sites for this technique are limited. So for HNC surgery in areas supplied by the mandibular nerve, a nerve block could be effectively employed. It should be noted that MNB is an advanced procedure with a failure rate of $15 \%$ to $20 \%$; but based upon the evidence MNB is a viable pain management option when possible [53-54].

Debulking tumour mass can help to reduce pain as shown in the studies by Werner et al. [45] and Castro et al. [38]. They investigated the response of HNC when subjected to intratumoural CDDP/epi gel. Epinephrine is used in combination with Cisplatin due to its ability to cause vasoconstriction which decreases Cisplatin clearance allowing the cytotoxic agent to act on the tumour cells for longer periods [55]. Both trials used pain control as a secondary outcome. The use of a placebo in both trials is an uncommon feature in pain relief studies due to ethical complications, however, their use increases validity. Patient benefit was analysed in both trials and the following was concluded: injected intratumoural CDDP/epi gel significantly reduces pain in $\mathrm{HNC}$ patients. As the procedure is not curative the gel is a palliative option. Further investigation needs to be carried out in order to determine which type of tumours will respond to the gel and how these tumours can be detected, to reduce unnecessary and harmful treatment in patients.

Saxena et al. [43] compared the analgesic effects of ASA to Piroxicam in HNC patients in India. Both Aspirin and Piroxicam are NSAIDs with a similar action [56]. It was found that there was no statistically significant difference in the pain relief offered by the two drugs; however, Piroxicam had fewer incidences of side effects. Piroxicam also required fewer and smaller doses throughout the trial, making Piroxicam a superior option for pain relief in HNC patients.

The analgesic properties of BtxA were studied by Wittekindt et al. [46]. BtxA is neurotoxin acting on axon terminals. It was found that lower doses of BtxA were more effective at reducing pain than higher doses. The use of lower doses is advantageous as higher doses can cause antibody formation and affect neuromuscular transmission in muscle groups unrelated to the site of pain [57]. The participants in the trial had all undergone a neck dissection, so the use of low doses of BtxA can only be recommended as postoperative analgesia at present. Very few other RCTs have been carried out in this specific field $[\underline{58}, \underline{59}]$.

The study by Jovic et al. [40] concluded that Ketoprofen offered better analgesia than Metamizole over the 3-day period. Ketoprofen only provided statistically better analgesia on the third day, leading to arguments against its efficacy. As both analgesics offered good pain control for all patients, and with the increased risks associated with Ketoprofen, Metamizole may be a better NSAID to use despite Ketoprofen's greater pain control on day 3 .

Cervical epidural Morphine versus thoracic epidural morphine investigated in paper by Georgiou et al. [39] found cervical administration of Morphine decreased VAS pain scores more than thoracic administration. The large volume of side effects experienced in the cervical group, however, is an argument against its frequent use in $\mathrm{HNC}$ pain management.

Non-pharmacological methods of postoperative pain relief have been studied. Shoulder pain is a complication of neck dissection as the accessory nerve which supplies the shoulder may become damaged in the procedure [21]. McNeely et al. [27,47] investigated the use of 
PRET versus TP. They found that such progressive exercise significantly reduced pain, although the overall quality of life was similar to the TP group. McNeely et al. $[27,47]$ only included participants that had a shoulder dysfunction attributed to surgical complications; therefore, the generalised use of PRET or any other exercise regime cannot be recommended for all HNC patients postoperatively. PRET could however be incorporated into the management of neck dissection patients that suffer pain or shoulder disability following surgery.

Acupuncture therapy as was researched in the paper by Pfister et al. [48] produced results that support the belief that acupuncture can be used to manage HNC pain. Patients reported significantly less pain after receiving targeted acupuncture and this corresponds to the findings of multiple other trials. As acupuncture has few side effects and complications, in situations whereby conventional medicine has failed or a patient requests an alternative therapy, acupuncture would be a possible treatment.

The paper by Yagi et al. [35] compared IV Fentanyl and Piroxicam preoperatively versus a control treatment respectively. The results presented in their abstract lead to the conclusion that IV Fentanyl or postoperative Piroxicam are superior in controlling pain in comparison to a control regimen of Pentazocine intramuscular (IM) or suppository Diclofenac sodium. As no serious side effects were experienced in any group IV Fentanyl or preoperative Piroxicam would be suitable analgesics for the management of postoperative pain.

In all of the trials that were reviewed, sample sizes were relatively small. Furthermore, the research of pain is bound by its idiosyncratic nature and although some trials incorporated objective measurements such as morphine consumption, most involved VAS or patient benefit scoring which has implications on the reliability of the results.

It is important that pain scores are comparable within the literature. Pain is highly subjective and different factors (e.g. personal, social, and cultural) may influence the individual report of pain severity. Studies have shown that pain scores judged by professional observers differ from pain scores rated by the patients themselves. Further biases in the measurement of pain could be introduced when the pain intensity is evaluated in an interview by health professionals, especially when the interviewer is personally involved in the care or treatment of the patient. Because of this it is important that studies use reliable and valid instruments and describe the way they were applied [60]. Six studies included in this review used a VAS to measure the severity of pain $[\underline{35}, \underline{39}, \underline{41}, \underline{42}, \underline{44}, \underline{46}]$. A VAS can be presented in many ways but in common it is a horizontal line of which the left end indicates no pain and the right end very severe pain and the patient marks the line at the point they feel representative for their pain condition. VAS is popular in research comparing the effectiveness of analgesic drugs. This pain measurement is highly subjective but it is a good method for displaying the change of pain severity within individuals [61]. However patients need to be trained to use the scale because people do not always easily understand its conception [60].

The Treatments Goal Questionnaire (TGQ) was used in two studies $[\underline{38}, \underline{45}]$. The TGQ is a validated instrument in HNC patients. Patients and physicians select prospective treatment goals associated with the target tumour and one of eight "palliative" goals (e.g. improve pain control or physical appearance). The physician can chose one of three "preventive" goals (prevention of invasion, obstruction, or subcutaneous tumour from breaking through the skin) instead of the palliative goal. Achievement is met when the goal sustained for at least 28 days. The patient benefit describes the combined goal outcomes of physicians and patients $[\underline{62}, \underline{63}]$. In the study by Castro et al. [38] pain control was the most important "palliative" goal selected by physicians and patients which show the high relevance of pain management in $\mathrm{HNC}$ patients.

In contrast to the VAS a lower sore at the ConstantMurley instrument used by Pfister et al. [48] indicates a poorer outcome. The Constant- Murley- and the SPADI questionnaire are mainly instruments to assess the shoulder function and pain [64]. SPADI, used in the exercise studies by Mc Neely et al. $[\underline{27}, \underline{47}]$ is a valid and reliable instrument but when it is used repeatedly in one patient the minimal detectible change important to the patient is 18 points (MDC 95\%) and therefore the results need to be interpreted with caution [65]

Jovic et al. [40] assessed pain by VNS (0 - 10) every 2 hours during the 72 hours. During the night there was a break for six hours in which the nurse stopped interviewing the patients. Other studies measured the pain over different time intervals (e.g. over a 24 hours period, Georgiou et al. [39] or at baseline and after the intervention, Mc Neely et al. [47]. Because of this and other methodological differences between the studies direct comparisons of the pain control interventions should be made with caution. Future studies should present the assessment of pain in more detail explaining the instrument, way of application and time intervals for questioning the patients. This could minimize biases in pain measurement and contribute to higher comparability between studies.

It was shown that a large proportion of cancer patients (nearly one in two) had undertreated cancer pain [66] and suggested that the optimal control of chronic pain in cancer relies on an understanding of the underlying pathophysiology and molecular mechanisms 
involved [31]. Management of cancer pain requires proper pain assessment, availability of oral morphine, co-analgesics and use of advance technology, as well as increasing awareness among clinicians, caregivers and patients $[\underline{67}, \underline{68}]$.

\section{CONCLUSIONS}

This paper investigated a variety of pharmacological and non-pharmacological interventions for the management of head and neck cancer pain post-treatment. There was a variation in the quality of studies and only 2 out of the 13 studies could be directly compared. There is insufficient evidence from randomised clinical trials of head and neck cancer pain to advise on an optimal intervention for head and neck cancer pain.
The current recommendation to follow is the WHO pain ladder and this recommendation will stand until further studies of a higher standard are conducted.

\section{ACKNOWLEDGMENTS AND DISCLOSURE STATEMENTS}

We are grateful to the University of Aberdeen library staff for their help in conducting literature search and to Dr. Rajko Jovic, Mr. Athanasios E. Athanasiou from the journal Balkan Union of Oncology, and Dr. Orlando Guntinas-Lichius for providing full text of papers. Elena Voge worked on the project while taking part in an Erasmus student placement under the European Lifelong Learning Programme.

\section{REFERENCES}

1. National Cancer Institute. Head and Neck Cancer. URL: www.cancer.gov/cancertopics/types/head-and-neck

2. National Cancer Institute. Dictionary of cancer terms. URL: http://www.cancer.gov/cancertopics/factsheet/Sites-Types/ head-and-neck

3. Cancer Research UK. Oral Cancer- UK Incidence Statistics. URL: http://www.cancerresearchuk.org/cancer-info/ cancerstats/types/oral/incidence/uk-oral-cancer-incidence-statistics

4. Hakulinen T, Andersen A, Malker B, Pukkala E, Schou G, Tulinius H. Trends in cancer incidence in the Nordic countries. A collaborative study of the five Nordic Cancer Registries. Acta Pathol Microbiol Immunol Scand Suppl. 1986;288: 1-151. [Medline: $\underline{3465196]}$

5. IARC Working Group on the Evaluation of Carcinogenic Risks to Humans. Tobacco smoke and involuntary smoking. IARC Monogr Eval Carcinog Risks Hum. 2004;83:1-1438. [Medline: 15285078]

6. IARC Working Group on the Evaluation of Carcinogenic Risks to Humans. Alcohol consumption and ethyl carbamate. IARC Monogr Eval Carcinog Risks Hum. 2010;96:3-1383. [Medline: 21735939]

7. Warnakulasuriya S. Causes of oral cancer--an appraisal of controversies. Br Dent J. 2009 Nov 28;207(10):471-5. [Medline: 19946320] [doi: 10.1038/sj.bdj.2009.1009]

8. Hamilos DL, Thawley SE, Kramper MA, Kamil A, Hamid QA. Effect of intranasal fluticasone on cellular infiltration, endothelial adhesion molecule expression, and proinflammatory cytokine mRNA in nasal polyp disease. J Allergy Clin Immunol. 1999 Jan;103(1 Pt 1):79-87.. [Medline: 9893189]

9. Murthy AK, Galinsky D, Hendrickson FR. Hypopharynx. In: Laramore GE, editors. Radiation Therapy of Head and Neck Cancer. Berlin: Springer-Verlag; 1989. p 107-24. [doi: 10.1007/978-3-642-83501-8 9]

10. Samant S, Kumar P, Wan J. Concomitant radiation therapy and targeted cisplatin chemotherapy for the treatment of advanced pyriform sinus carcinoma: disease control and preservation of organ function. Head Neck. 1999 Oct; 21 (7): 595-601. [Medline: 10487945] [doi: 10.1002/(SICI)1097-0347(199910)21:7<595::AID-HED2>3.0.CO;2-J]

11. Hakulinen T, Andersen A, Malker B, Pukkala E, Schou G, Tulinius H. Trends in cancer incidence in the Nordic countries. A collaborative study of the five Nordic Cancer Registries. Acta Pathol Microbiol Immunol Scand Suppl. 1986;288:1151. [Medline: 12057086] [doi: 10.1007/s11864-002-0040-1]

12. National Cancer Institute 2012, Hypopharyngeal cancer treatment: Treatment option Overview. URL: www.cancer.gov/ cancertopics/pdq/treatment/hypopharyngeal/HealthProfessional/Page4

13. National Cancer Institute 2012. Lip and Oral Cavity treatment: Treatment option Overview. URL: www.cancer.gov/ cancertopics/pdg/treatment/lip-and-oral-cavity/HealthProfessional/page4

14. Martin EA. Oxford Concise Medical Dictionary. 8th ed. Oxford: OUP Oxford. 2010.

15. Wells N, Pasero C, McCaffery M. Improving the Quality of Care Through Pain Assessment and Management. In: Hughes RG, editor. Patient Safety and Quality: An Evidence-Based Handbook for Nurses. Rockville (MD): Agency for Healthcare Research and Quality (US); 2008 Apr. Chapter 17 [Medline: 21328759]

16. Huskisson EC. Measurement of pain. Lancet. 1974 Nov 9;2(7889):1127-31. [Medline: 4139420] [doi: $10.1016 / \mathrm{S} 0140-6736(74) 90884-8$ ]

17. Hartrick CT, Kovan JP, Shapiro S. The numeric rating scale for clinical pain measurement: a ratio measure? Pain Pract. 2003 Dec;3(4):310-6. [Medline: 17166126] 
18. Wong-Baker Faces Foundation. Wong-Baker FACES Pain Rating Scale. URL: www.wongbakerfaces.org/

19. Ambuel B, Hamlett KW, Marx CM, Blumer JL. Assessing distress in pediatric intensive care environments: the COMFORT scale. J Pediatr Psychol. 1992 Feb;17(1):95-109. [Medline: 1545324] [doi: 10.1093/jpepsy/17.1.95]

20. Ritter PL, González VM, Laurent DD, Lorig KR. Measurement of pain using the visual numeric scale. J Rheumatol. 2006 Mar;33(3):574-80. [Medline: 16511926]

21. Kou P, Williams JE. Pain Control in Head and Neck Cancer. In: Agulnik M, editor. Head and Neck Cancer. InTech 2012. p. 351-371.

22. Williams JE, Yen JT, Parker G, Chapman S, Kandikattu S, Barbachano Y. Prevalence of pain in head and neck cancer out-patients. J Laryngol Otol. 2010 Jul;124(7):767-73. Epub 2010 May 4. [Medline: 20438658] [doi: 10.1017/S002221511000040X]

23. Chaplin JM, Morton RP. A prospective, longitudinal study of pain in head and neck cancer patients. Head Neck. 1999 Sep;21(6):531-7. [Medline: 10449669] [doi: 10.1002/(SICI)1097-0347(199909)21:6<531::AID-HED6>3.0.CO;2-M]

24. Macfarlane TV, Wirth T, Ranasinghe S, Ah-See KW, Renny N, Hurman D. Head and Neck cancer pain: Systematic review of prevalence and associated factors. J Oral and Maxillofac Res. 2012 Mar; 3(1):e1. [doi: 10.5037/jomr.2012.3101] URL: http://www.ejomr.org/JOMR/archives/2012/1/e1/v3n1e1ht.htm

25. Breivik H, Cherny N, Collett B, de Conno F, Filbet M, Foubert AJ, Cohen R, Dow L. Cancer-related pain: a panEuropean survey of prevalence, treatment, and patient attitudes. Ann Oncol. 2009 Aug;20(8):1420-33. Epub 2009 Feb 24. [Medline: 19244085] [doi: 10.1093/annonc/mdp001] [FREE Full Text]

26. Vecht CJ, Hoff AM, Kansen PJ, de Boer MF, Bosch DA. Types and causes of pain in cancer of the head and neck. Cancer. 1992 Jul 1;70(1):178-84. [Medline: 1606540] [doi: 10.1002/1097-0142(19920701)70:1<178::AID-CNCR2820700128>3.0.CO;2-E]

27. McNeely ML, Parliament MB, Seikaly H, Jha N, Magee DJ, Haykowsky MJ, Courneya KS. Effect of exercise on upper extremity pain and dysfunction in head and neck cancer survivors: a randomized controlled trial. Cancer. 2008 Jul 1;113(1):214-22. [Medline: 18457329] [doi: 10.1002/cncr.23536]

28. World Health Organization. Cancer: WHO's pain ladder. URL: www.who.int/cancer/palliative/painladder/en/

29. Zech DF, Grond S, Lynch J, Hertel D, Lehmann KA. Validation of World Health Organization Guidelines for cancer pain relief: a 10-year prospective study. Pain. 1995 Oct;63(1):65-76. [Medline: 8577492] [doi: 10.1016/0304-3959(95)00017-M]

30. Grond S, Zech D, Lynch J, Diefenbach C, Schug SA, Lehmann KA. Validation of World Health Organization guidelines for pain relief in head and neck cancer. A prospective study. Ann Otol Rhinol Laryngol. 1993 May;102(5):342-8. [Medline: $\underline{7683853}$ ]

31. Cancer pain management. British Pain Society, London, UK 2010. URL: http://www.britishpainsociety.org/book_cancer= pain.pdf

32. AzevedoSãoLeãoFerreiraK,KimuraM,JacobsenTeixeiraM.TheWHOanalgesicladderforcancerpaincontrol,twentyyears of use. How much pain relief does one get from using it? Support Care Cancer. 2006 Nov;14(11):1086-93. Epub 2006 Jun 8. Review. [Medline: 16761128 ] [doi: $10.1007 / \mathrm{s} 00520-006-0086-\mathrm{x}]$

33. Moher D, Liberati A, Tetzlaff J, Altman DG; PRISMA Group. Preferred reporting items for systematic reviews and metaanalyses: the PRISMA statement. Int J Surg. 2010;8(5):336-41. Epub 2010 Feb 18. Erratum in: Int J Surg. 2010;8(8):658. [Medline: 20171303]

34. The Cochrane Library. URL: http://www.thecochranelibrary.com/view/0/index.html

35. Yagi Y, Sakaguchi H, Noda M, Noda N, Sakamoto M, Taen A, Terasaki H. Postoperative pain management after head and neck surgery. Journal of Japanese Dental Society of Anesthesiology. 1997; 25 (2): 163-8.

36. Crombie IK. The Pocket Guide to Critical Appraisal. London: BMJ publishing group. 2011.

37. Higgins JPT, Green S. Cochrane Handbook for Systematic Reviews of Interventions. URL: http://www.mrc-bsu.cam. ac.uk/cochrane/handbook/chapter 8/table 8 5 a the cochrane collaborations tool for assessing.htm

38. Castro DJ, Sridhar KS, Garewal HS, Mills GM, Wenig BL, Dunphy FR 2nd, Costantino PD, Leavitt RD, Stewart ME, Orenberg EK. Intratumoral cisplatin/epinephrine gel in advanced head and neck cancer: a multicenter, randomized, double-blind, phase III study in North America. Head Neck. 2003 Sep;25(9):717-31. [Medline: 12953307] [doi: 10.1002/hed.10261]

39. Georgiou L, Louizos A, Sklavou C, Manolopoulos L, Yiotakis I, Adamopoulos G. Cervical versus thoracic epidural morphine for the treatment of head and neck cancer pain. Ann Otol Rhinol Laryngol. 2000 Jul;109(7):676-8. [Medline: 10903050]

40. Jovic R, Dragicevic D, Komazec Z, Sabo A. Ketoprofen is superior to metamizole in relieving postoperative pain after head and neck tumor operation. J BUON. 2008 Oct-Dec;13(4):519-23. [Medline: 19145673]

41. Plantevin F, Pascal J, Morel J, Roussier M, Charier D, Prades JM, Auboyer C, Molliex S. Effect of mandibular nerve block on postoperative analgesia in patients undergoing oropharyngeal carcinoma surgery under general anaesthesia. $\mathrm{Br} \mathrm{J}$ Anaesth. 2007 Nov;99(5):708-12. Epub 2007 Sep 19. [Medline: 17884802] [doi: 10.1093/bja/aem242] [FREE Full Text]

42. Roussier M, Mahul P, Pascal J, Baylot D, Prades JM, Auboyer C, Molliex S. Patient-controlled cervical epidural fentanyl compared with patient-controlled i.v. fentanyl for pain after pharyngolaryngeal surgery. Br J Anaesth. 2006 Apr;96(4):492-6. Epub 2006 Feb 13. [Medline: 16476697] [doi: 10.1093/bja/ael025] [FREE Full Text] 
43. Saxena A, Andley M, Gnanasekaran N. Comparison of piroxicam and acetylsalicylic acid for pain in head and neck cancers: a double-blind study. Palliat Med. 1994;8(3):223-9. [Medline: 7952372] [doi: 10.1177/026921639400800306]

44. Singhal AK, Mishra S, Bhatnagar S, Singh R. Epidural morphine analgesia compared with intravenous morphine for oral cancer surgery with pectoralis major myocutaneous flap reconstruction. Acta Anaesthesiol Scand. 2006 Feb;50(2):234-8. [Medline: 16430548 ] [doi: $\underline{10.1111 / \text { j.1399-6576.2006.00924.x] }}$

45. Werner JA, Kehrl W, Pluzanska A, Arndt O, Lavery KM, Glaholm J, Dietz A, Dyckhoff G, Maune S, Stewart ME, Orenberg EK, Leavitt RD. A phase III placebo-controlled study in advanced head and neck cancer using intratumoural cisplatin/epinephrine gel. Br J Cancer. 2002 Oct 21;87(9):938-44. [Medline: 12434280] [doi: 10.1038/sj.bjc.6600588] [FREE Full Text]

46. Wittekindt C, Liu WC, Preuss SF, Guntinas-Lichius O. Botulinum toxin A forneuropathic pain after neck dissection: a dosefinding study. Laryngoscope. 2006 Jul;116(7):1168-71. [Medline: 16826054] [doi: 10.1097/01.mlg.0000217797.05523.75]

47. McNeely ML, Parliament M, Courneya KS, Seikaly H, Jha N, Scrimger R, Hanson J. A pilot study of a randomized controlled trial to evaluate the effects of progressive resistance exercise training on shoulder dysfunction caused by spinal accessory neurapraxia/neurectomy in head and neck cancer survivors. Head Neck. 2004 Jun;26(6):518-30. [Medline: 15162353] [doi: 10.1002/hed.20010]

48. Pfister DG, Cassileth BR, Deng GE, Yeung KS, Lee JS, Garrity D, Cronin A, Lee N, Kraus D, Shaha AR, Shah J, Vickers AJ. Acupuncture for pain and dysfunction after neck dissection: results of a randomized controlled trial. J Clin Oncol. 2010 May 20;28(15):2565-70. Epub 2010 Apr 20. [Medline: 20406930] [doi: 10.1200/JCO.2009.26.9860] [FREE Full Text]

49. Roach KE, Budiman-Mak E, Songsiridej N, Lertratanakul Y. Development of a shoulder pain and disability index. Arthritis Care Res. 1991 Dec;4(4):143-9. [Medline: 11188601] [doi: 10.1002/art.1790040403]

50. Drug Information Online. Sublimaze Description. URL: www.drugs.com/pro/sublimaze.html

51. Bandolier. Epidurals and risk: it all depends. URL: www.medicine.ox.ac.uk/bandolier/band159/b159-3.html

52. Medscape. Malignant Tumours of the Larynx. URL: www.emedicine.medscape.com/article/848592-overview

53. Sinard RJ, Netterville JL, Garrett CG, Ossoff RH. Cancer of the larynx. In: Myers EN, Suen JY, editors. Cancer of the head and neck. Philadelphia: WB Saunders; 1996. 403-6.

54. Gaum LI, Moon AC. The "ART" mandibular nerve block: a new approach to accomplishing regional anesthesia. J Can Dent Assoc. 1997 Jun;63(6):454-9. Review. Erratum in: J Can Dent Assoc 1997 Sep;63(8):605. [Medline: 9203779]

55. Mok TS, Kanekal S, Lin XR, Leung TW, Chan AT, Yeo W, Yu S, Chak K, Leavitt R, Johnson P. Pharmacokinetic study of intralesional cisplatin for the treatment of hepatocellular carcinoma. Cancer. 2001 Jun 15;91(12):2369-77. [Medline: 11413527] [doi: 10.1002/1097-0142(20010615)91:12<2369::AID-CNCR1270>3.0.CO;2-3]

56. Kurumbail RG, Stevens AM, Gierse JK, McDonald JJ, Stegeman RA, Pak JY, Gildehaus D, Miyashiro JM, Penning TD, Seibert K, Isakson PC, Stallings WC. Structural basis for selective inhibition of cyclooxygenase-2 by anti-inflammatory agents. Nature. 1996 Dec 19-26;384(6610):644-8. Erratum in: Nature 1997 Feb 6;385(6616):555. [Medline: $\underline{8967954]}$ [doi: $/ 10.1038 / 384644 \mathrm{a} 0]$

57. Foran PG, Mohammed N, Lisk GO, Nagwaney S, Lawrence GW, Johnson E, Smith L, Aoki KR, Dolly JO. Evaluation of the therapeutic usefulness of botulinum neurotoxin B, C1, E, and F compared with the long lasting type A. Basis for distinct durations of inhibition of exocytosis in central neurons. J Biol Chem. 2003 Jan 10;278(2):1363-71. Epub 2002 Oct 14. [Medline: 12381720] [doi: 10.1074/jbc.M209821200] [FREE Full Text]

58. Costa J, Espírito-Santo C, Borges A, Ferreira JJ, Coelho M, Moore P, Sampaio C. Botulinum toxin type A therapy for cervical dystonia. Cochrane Database Syst Rev. 2005 Jan 25;(1):CD003633. Review. [doi: 10.1002/14651858.CD003633.pub2]

59. Jabbari B. Botulinum neurotoxins in the treatment of refractory pain. Nat Clin Pract Neurol. 2008 Dec;4(12):676-85. [Medline: 19043424] [doi: 10.1038/ncpneuro0948]

60. Cleeland CS. Measurement and prevalence of pain in cancer. Semin Oncol Nurs. 1985 May;1(2):87-92. [Medline: 3849841] [doi: 10.1016/S0749-2081(85)80041-3]

61. Gould D, Kelly D, Goldstone L, Gammon J. Examining the validity of pressure ulcer risk assessment scales: developing and using illustrated patient simulations to collect the data. J Clin Nurs. 2001 Sep;10(5):697-706. [Medline: 11822520] [doi: 10.1046/j.1365-2702.2001.00525.x]

62. Werner J, Castro D, Sridhar K, Garewal H, Arndt O, Kehrl W, Pluzanska A, Dunphy F, Stewart M. A new instrument to assess improvements in quality of life (QoL) attributed to local control of head and neck squamous cell carcinoma (HNSCC) [abstract]. Proc Am Soc Clin Oncol.2000;19:620.

63. Mackowiak J, Stewart M, Leavitt R, Burris III H. Validation of the Treatment Goals Questionnaire ${ }^{\odot}$ (TGQ): a new instrument to assess patient benefit following treatment of squamous cell carcinoma of the head and neck (HNSCC) with intratumoral cisplatin/epinephrine injectable gel [abstract]. Proc Am Soc Clin Oncol.2001;20:232. URL: http://www. asco.org/ASCOv2/Meetings/Abstracts?\&vmview=abst detail view\&confID=10\&abstractID=925

64. Boehm D, Wollmerstedt N, Doesch M, Handwerker M, Mehling E, Gohlke F. [Development of a questionnaire based on the Constant-Murley-Score for self-evaluation of shoulder function by patients]. Unfallchirurg. 2004 May;107(5):397402. German. [Medline: 15060778 ] 
65. Breckenridge JD, McAuley JH. Shoulder Pain and Disability Index (SPADI). J Physiother. 2011;57(3):197. [Medline: 21843839] [doi: 10.1016/S1836-9553(11)70045-5]

66. Deandrea S, Montanari M, Moja L, Apolone G. Prevalence of undertreatment in cancer pain. A review of published literature. Ann Oncol. 2008 Dec;19(12):1985-91. Epub 2008 Jul 15. [Medline: 18632721] [doi: 10.1093/annonc/mdn419] [FREE Full Text]

67. Thapa D, Rastogi V, Ahuja V. Cancer pain management-current status. JAnaesthesiol Clin Pharmacol. 2011 Apr;27(2): 162-8. [Medline: 21772673] [doi: 10.4103/0970-9185.81820]

68. Akashi M, Yano E, Aruga E. Under-diagnosis of pain by primary physicians and late referral to a palliative care team. BMC Palliat Care. 2012 Jun 7;11:7. [Medline: 22676380] [doi: 10.1186/1472-684X-11-7] [FREE Full Text]

\section{To cite this article:}

Trotter PB, Norton LA, Loo AS, Munn JI, Voge E, Ah-See KW, Macfarlane TV. Pharmacological and Other Interventions for Head and Neck Cancer Pain: a Systematic Review.

J Oral Maxillofac Res 2012;3(4):e1

URL: http://www.ejomr.org/JOMR/archives/2012/4/e1/v3n4e1ht.pdf

doi: $10.5037 /$ jomr.2012.3401

Copyright (C) Trotter PB, Norton LA, Loo AS, Munn JI, Voge E, Ah-See KW, Macfarlane TV. Accepted for publication in the JOURNAL OF ORAL \& MAXILLOFACIAL RESEARCH (http://www.ejomr.org), 20 December 2012.

This is an open-access article, first published in the JOURNAL OF ORAL \& MAXILLOFACIAL RESEARCH, distributed under the terms of the Creative Commons Attribution-Noncommercial-No Derivative Works 3.0 Unported License, which permits unrestricted non-commercial use, distribution, and reproduction in any medium, provided the original work and is properly cited. The copyright, license information and link to the original publication on (http://www.ejomr.org) must be included. 
Table 1. Description of studies included in the review

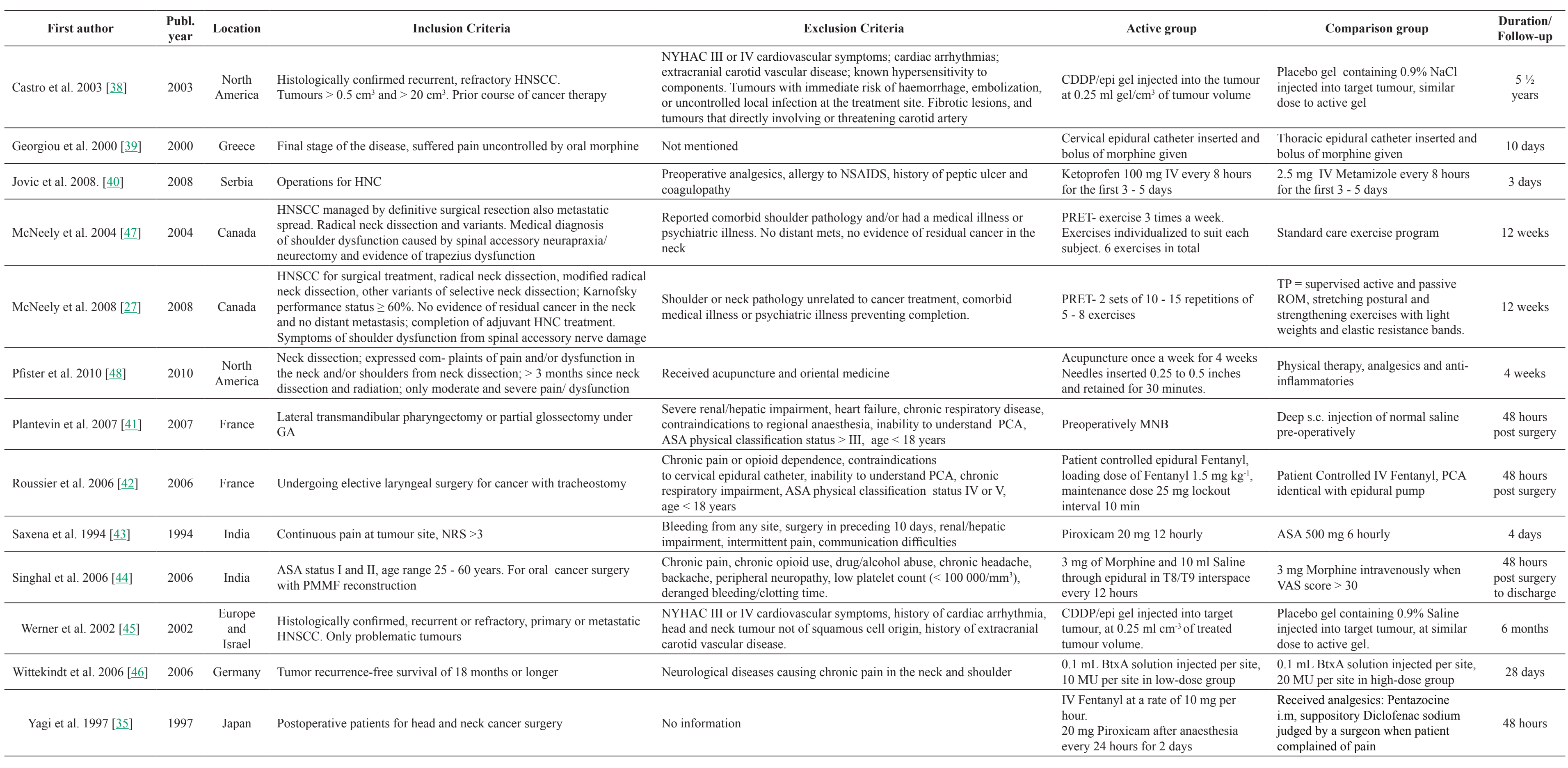

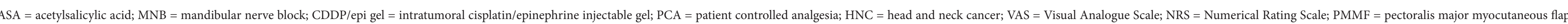
$\mathrm{ASA}=$ acetylsalicylic acid; $\mathrm{MNB}=$ mandibular nerve block; $\mathrm{CDDP} / \mathrm{epi}$ gel $=$ intratumoral cisplatin/epinephrine injectable gel; $\mathrm{PCA}=$ patient controlled analgesia; $\mathrm{HNC}=$ head and neck cancer; $\mathrm{VAS}=\mathrm{Visual}$ Analogue $\mathrm{Scale} ; \mathrm{NRS}=\mathrm{IV}=$ intravenous; s.c. = control subcutaneous; $\mathrm{GA}=$ general anaesthesia; $\mathrm{ROM}=$ range of motion; $\mathrm{HNSCC}=$ squamous cell carcinoma of the head and neck; PRET = progressive resistance exercise training; $\mathrm{TP}=$ exercise protocol. 
Table 2. Description of study results

\begin{tabular}{|c|c|c|c|c|}
\hline Author & $\begin{array}{l}\text { Participant Information: } \\
\text { (Patient numbers, } \\
\text { Average age (years), } \\
\text { Male:Female, } \\
\text { Other) }\end{array}$ & $\begin{array}{l}\text { Dropout rate } \\
\text { (Active group vs } \\
\text { Comparison group) }\end{array}$ & Method of pain measurement & Results \\
\hline Castro et al. 2003 [38] & $\begin{array}{l}62 \text { active, } 24 \text { placebo } \\
63(33-87) \text { vs. } 61(40-82) \\
50: 12 \text { vs. } 17: 7\end{array}$ & $1.6 \%(1 / 63)$ vs 0 & $\begin{array}{l}\text { Treatment goals questionnaire; } \\
\text { Quality of life (FACT, HN and KPS) }\end{array}$ & $\begin{array}{l}37 \%(23 / 62) \text { patients in active group experienced patient benefit, } 34 \% \text { of which was pain control. } \\
12 \%(3 / 24) \text { in the placebo group experienced patient benefit; } \mathrm{P}=0.25\end{array}$ \\
\hline Georgiou et al. 2000 [39] & $\begin{array}{l}16 \text { thoracic epidural, } 13 \text { cervical epidural } \\
68 \text { vs. } 69 \\
15: 1 \text { vs. } 13: 0\end{array}$ & 0 & VAS & $\begin{array}{l}\text { Cervical epidural morphine decreased pain based on VAS on days } 1,2,5 \text { and } 10 \text {. Duration of analgesia for cervical epidural approximately } \\
4 \text { hours longer than thoracic epidural }(\mathrm{P}<0.5) \text {. Cervical epidural required small doses }\end{array}$ \\
\hline Jovic et al. 2008 [40] & $\begin{array}{l}30 \text { Ketoprofen, } 30 \text { Metamizole } \\
60.2(43-79) \text { vs. } 54.8(32-72) \\
25: 5 \text { vs. } 27: 3\end{array}$ & 0 & VNS & $\begin{array}{l}\text { Both medications effective. Analgesia better with Ketoprofen but not significant over the first } 2 \text { days. On day } 3 \text { the rating score was } \\
\text { significantly lower for patients on Ketoprofen than Metamizole }(\mathrm{P}<0.05)\end{array}$ \\
\hline McNeely et al. 2004 [47] & $\begin{array}{l}10 \text { exercise group } \\
10 \text { control group } \\
60 \text { vs. } 61 \\
7: 1,7: 2\end{array}$ & $\begin{array}{l}20 \%(2 / 10) \text { vs; } \\
\quad 10 \%(1 / 10)\end{array}$ & SPADI & $\begin{array}{l}\text { PRET has a beneficial effect on pain. Overall pain score decreased in active group by } 17 \% \text { compared to a slight increase }(1.7 \%) \text { in control } \\
\text { group. }\end{array}$ \\
\hline McNeely et al. $2008[\underline{27}]$ & $\begin{array}{l}27 \text { PRET group, } 25 \text { TP group } \\
57(43-76) \text { vs. } 53(32-76) \\
20: 7 \text { vs. } 17: 8\end{array}$ & $7.4 \%(2 / 27)$ vs $12 \%(3 / 25)$ & SPADI & $\begin{array}{l}\text { PRET group experienced decreased SPADI scores from baseline of } 19.6 \text { to } 7.6 \text { and a mean change of }-11.8 \text { compared to TP with a mean } \\
\text { change of }-7,4 \text {. }\end{array}$ \\
\hline Pfister et al. 2010 [48] & $\begin{array}{l}28 \text { active, } 30 \text { placebo } \\
61 \text { vs. } 57 \\
15: 13 \text { vs. } 23: 7\end{array}$ & $\begin{array}{l}17.7 \%(6 / 34) \text { vs } \\
11.1 \%(4 / 36)\end{array}$ & $\begin{array}{l}\text { Composite score of pain, function, and } \\
\text { activities of daily living provided by the } \\
\text { Constant-Murley instrument }\end{array}$ & $\begin{array}{l}\text { Acupuncture was superior to control for all outcome measures. Acupuncture patients scored } 11.2 \text { points higher than controls on the } \\
\text { Constant-Murley scale }(95 \% \mathrm{CI}, 3.0 \text { to } 19.3 ; \mathrm{P}=0.008) \text {. }\end{array}$ \\
\hline Plantevin et al. 2007 [41] & $\begin{array}{l}21 \text { MNB group, } 21 \text { placebo group } \\
55 \text { ( } 40 \text { - 70) vs. } 52(37-76) \\
18: 1 \text { vs } 19: 1\end{array}$ & $9.5 \%(2 / 21)$ vs $4.8 \%(1 / 21)$ & VAS, morphine consumption & $\begin{array}{l}\text { Morphine consumption at } 24 \mathrm{~h} \text { : MNB group } 26.7(18) \mathrm{mg} \text { vs. control group } 48.5(26.3) \mathrm{mg} \text {; } \\
\text { Morphine consumption over each } 2 \mathrm{~h} \text { time interval was lower in MNB group for the first } 12 \mathrm{hours} \text {; No difference at } 48 \mathrm{~h}\end{array}$ \\
\hline Roussier et al. 2006 [42] & $\begin{array}{l}22 \text { in PCA-IV route, } 20 \text { in PCA-Epidural route } \\
58 \text { ( } 44-81) \text { vs. } 57(33-71) \\
20: 2 \text { vs } 19: 1 \text { - } 1 \text { with chronic bronchitis } \\
\text { All smokers with che }\end{array}$ & $4.8 \%(1 / 21)$ vs $12 \%(3 / 25)$ & $\begin{array}{l}\text { VAS, Fentanyl consumption and number of } \\
\text { PCA demands. }\end{array}$ & $\begin{array}{l}\text { VAS pain scores at rest in the Epidural group were } 1.75(3.25) \text { and } 1.75(3) \text { vs } 5.5(5.25) \text { and } 3.25 \text { (3) in the IV group, } 2 \text { and } 6 \mathrm{~h} \text { after } \\
\text { surgery respectively. } \\
\text { Cumulative Fentanyl consumption: Epidural group: } 1412 \mathrm{mg} \text { (912), IV group: } 1287 \mathrm{mg}(1200) \text {; } \\
\text { Cumulative number of demands: Epidural group: } 68 \text { ( } 76), \mathrm{IV} \text { group: } 75 \text { (122) }\end{array}$ \\
\hline Saxena et al. 1994 [43] & $\begin{array}{l}25 \text { in Piroxicam, } 25 \text { ASA } \\
56.2(30-79) \text { vs. } 59.9(31-79) \\
23: 2 \text { vs. } 22: 3\end{array}$ & $20 \%(5 / 25)$ vs $36 \%(9 / 25)$ & Review questionnaire including pain NRS & $\begin{array}{l}\text { NRS (SD) initially was } 7.05 \text { (1.97) in Piroxicam group and } 5.8(1.96) \text { in ASA group. } \\
\text { Mean pain score (SD) in Piroxicam group was 5.2 (2.73) and in ASA group was } 3.31 \text { (1.56) after } 4 \text { days of treatment. }\end{array}$ \\
\hline Singhal et al. 2006 [녀] & $\begin{array}{l}30 \text { active, } 30 \text { placebo } \\
50.30(37.4-62.9) \text { vs. } 48.60(37.60-59.60) \\
21: 9 \text { vs. } 27: 3\end{array}$ & 0 & VAS & Epidural morphine provided better analgesia than IV morphine $(\mathrm{P}<0.05)$ \\
\hline Werner et al. 2002 [도] & $\begin{array}{l}57 \text { active, } 35 \text { placebo } \\
60(37-82) \text { vs } 62(43-84) \\
45: 12 \text { vs } 30: 5 \\
\text { More primary tumours in active group, more } \\
\text { metastatic in placebo }\end{array}$ & $\begin{array}{l}56.1 \%(32 / 57) \\
\text { vs } \\
82.9 \%(29 / 35)\end{array}$ & $\begin{array}{l}\text { Treatment Goals Questionnaire; } \\
\text { Quality of life (FACT, HN) }\end{array}$ & $\begin{array}{l}19 \%(11 / 57) \text { patients in active group achieved patient benefit including pain control } \\
9 \%(3 / 35) \text { patients in placebo group achieved patient benefit; } \mathrm{P}=0.24\end{array}$ \\
\hline Wittekindt et al. 2006 [46] & $\begin{array}{l}\text { 13 low dose group, } 10 \text { high dose group } \\
21: 2\end{array}$ & 0 & VAS & $\begin{array}{l}56.5 \% \text { (13/23) experienced pain relief with } 69.2 \%(9 / 13) \text { experiencing pain relief in the low dose group compared to } 40 \%(4 / 10) \text { for the } \\
\text { high dose group. No statistically significant decrease in VAS score at baseline and } 28 \text { days }(\mathrm{P}=0.15)\end{array}$ \\
\hline Yagi et al. $1997[\underline{35}]$ & $\begin{array}{l}10 \text { IV Fentanyl group, } 10 \text { Piroxicam, } 10 \\
\text { control group }\end{array}$ & No information & $\begin{array}{l}\text { VAS, Verbal Pain score } \\
(0-3) \text {, face scale }\end{array}$ & $\begin{array}{l}\text { Continuous intravenous infusion of a small dose of Fentanyl or periodical administration of Piroxicam prior to surgery produced better } \\
\text { postoperative analgesia after head and neck surgery in comparison to the control group. }\end{array}$ \\
\hline
\end{tabular}

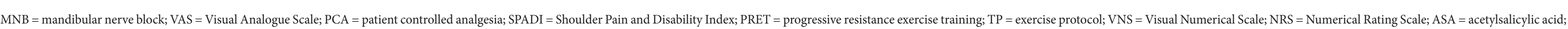
HN = head and neck; FACT = Functional Assessment of Cancer Therapy Head and Neck ; KPS = Karnofsky Performance Status. 
Table 3A. Critical appraisal table

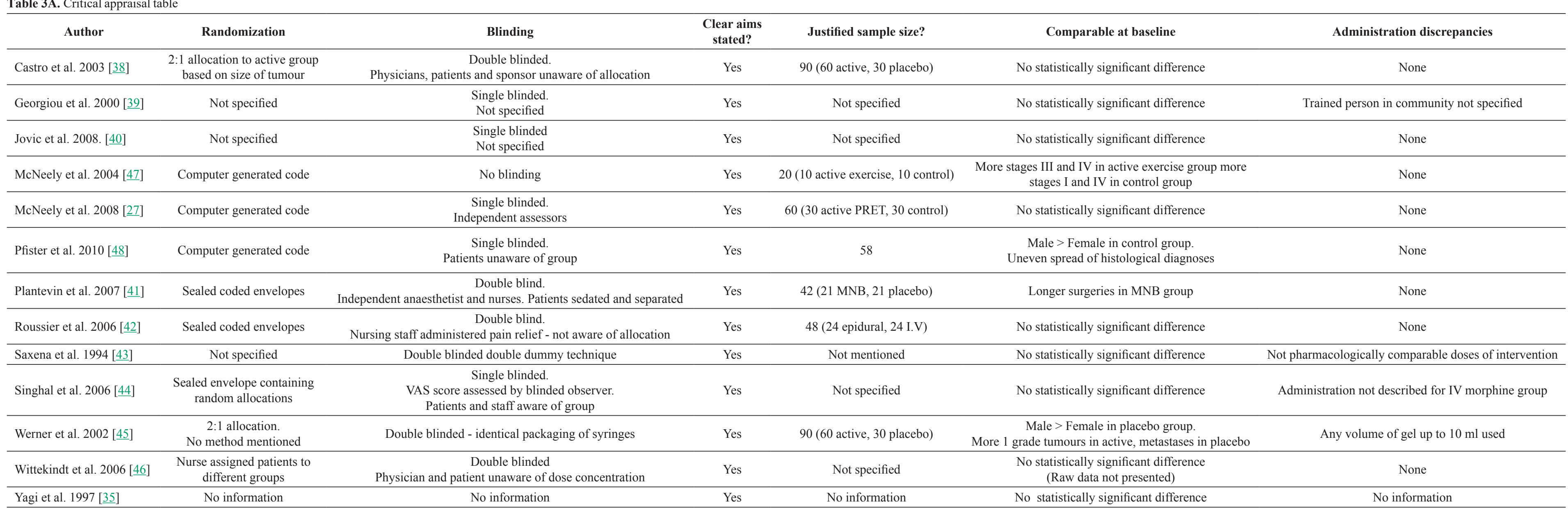

$\mathrm{MNB}=$ mandibular nerve block; $\mathrm{PRET}$ = progressive resistance exercise training; VAS = Visual Analogue Scale. 
Table 3B. Critical appraisal table

\begin{tabular}{|c|c|c|c|c|c|c|}
\hline Author & Any untoward events & $\begin{array}{l}\text { Unusual characteristics of } \\
\text { sample }\end{array}$ & $\begin{array}{l}\text { Intention to } \\
\text { treat basis? }\end{array}$ & $\begin{array}{l}\text { Basic data described } \\
\text { adequately }\end{array}$ & $\begin{array}{l}\text { Do the numbers } \\
\text { add up }\end{array}$ & Statistical methods described \\
\hline Castro et al. 2003 [38] & $\begin{array}{l}\text { Protocol was amended in the trial because of severe side effects and } 2 \\
\text { deaths related to treatment with CDDP/epi gel. } \\
\text { Enclosure of tumors }>20 \mathrm{~cm}^{3} \text { that invaded or were in close proximity } \\
\text { to the carotid artery. }\end{array}$ & $\begin{array}{l}\text { All patients in at least } 2^{\text {nd }} \\
\text { recurrence } \\
92 \% \text { treated with } \geq 2 \\
\text { of: surgery, radiation, } \\
\text { chemotherapy }\end{array}$ & Not specified & Yes, tabular & Yes & $\begin{array}{l}\text { - Computer analysis } \\
\text { - Exact Clopper-Pearson for confidence intervals } \\
\text { - Fisher's exact test-compare rates across patient groups } \\
\text { - Cochran-Mantel-Haenszel. For stratified comparisons } \\
\text { - MULTITEST- for P values }\end{array}$ \\
\hline Georgiou et al. 2000 [39] & None specified & Final stage of the disease & Not specified & Yes, Graphically & Yes & $\begin{array}{l}\text { - Computer analysis } \\
\text { - students t-test for statistical analysis of results } \\
\text { - ANOVAs for pain score }\end{array}$ \\
\hline Jovic et al. 2008 [40] & None specified & $\begin{array}{l}10 \% \text { had histologically benign } \\
\text { tumour }\end{array}$ & Not specified & $\begin{array}{l}\text { Yes, tabular and } \\
\text { graphically }\end{array}$ & Yes & Not mentioned \\
\hline McNeely et al. 2008 [27] & $\begin{array}{l}\text { One patient in PRET group had to leave the study due to pain } \\
\text { considered to be a result of exercise }\end{array}$ & $\begin{array}{l}\text { Wide variety in time between } \\
\text { surgery to entering the study }\end{array}$ & Yes & Yes, tabular & Yes & $\begin{array}{l}\text { - Independent samples student } t \text { test for continuous data and person Chi-squared test for categorical } \\
\text { data }\end{array}$ \\
\hline Pfister et al. $2010[\underline{48}]$ & None specified & None & Yes & Yes, tabular & Yes & $\begin{array}{l}\text { - Computer analysis } \\
\text { - Stata } 9.2 \text { - No details of specific tests }\end{array}$ \\
\hline Plantevin et al. 2007 [41] & None specified & None & Not specified & Yes, tabular & Yes & $\begin{array}{l}\text { - Computer analysis } \\
\text { - Mann-Whitney U test for comparison of groups } \\
\text { - Chi-squared for qualitative variables } \\
\text { - Tukey correction }\end{array}$ \\
\hline Roussier et al. 2006 [42] & None specified & $\begin{array}{l}\text { All patients chronic smokers } \\
\text { with bronchitis }\end{array}$ & Not specified & Yes, tabular & Yes & $\begin{array}{l}\text { - Computer analysis } \\
\text { - Fisher test for categorical data } \\
\text { - Mann-Whitney U test for VAS score, Fentanyl consumption and PCA demand } \\
\text { - Tukey correction }\end{array}$ \\
\hline Saxena et al. 1994 [펴] & Large drop out & $\begin{array}{l}\text { Excluded for communication } \\
\text { difficulties }\end{array}$ & Not specified & Yes, tabular & Yes & $\begin{array}{l}\text { - t-test for mean reduction of pain score } \\
\text { - Chi-quared for comparison of groups }\end{array}$ \\
\hline Singhal et al. 2006 [44] & None specified & None & Yes & $\begin{array}{l}\text { Yes, graph and } \\
\text { tabular }\end{array}$ & Yes & $\begin{array}{l}\text { - Student } t \text { test assess statistical dose required } \\
\text { - Wilcoxon test for VAS pain scores } \\
\text { - Bonferroni adjustments for multiple comparisons } \\
\text { - Two way ANOVA - for trend significance }\end{array}$ \\
\hline Werner et al. 2002 [45] & Large drop out & $\begin{array}{l}\text { Only most problematic } \\
\text { tumours }\end{array}$ & Yes & Yes, tabular & Yes & $\begin{array}{l}\text { - 2-tailed } a \text { test for power } \\
\text { - CMH for comparison of end points } \\
\text { - Fisher analyses of strata }\end{array}$ \\
\hline Wittekindt et al. 2006 [부 & None specified & $\begin{array}{l}\text { All undergone conservative } \\
\text { treatment for neck and } \\
\text { shoulder pain after neck } \\
\text { dissection }\end{array}$ & Not specified & $\begin{array}{l}\text { Yes, tabular and } \\
\text { graph }\end{array}$ & Yes & $\begin{array}{l}\text { - Computer analysis } \\
\text { - Wilcoxon test for dependent groups used for comparison of VAS before and after therapy } \\
\text { - Chi-squared for different treatment outcomes }\end{array}$ \\
\hline Yagi et al. 1997 [35] & No information & No information & $\begin{array}{c}\text { No } \\
\text { information }\end{array}$ & No information & No information & No information \\
\hline
\end{tabular}

$\mathrm{CDDP} /$ epi gel = intratumoral cisplatin/epinephrine injectable gel; $\mathrm{VAS}$ = Visual Analogue Scale; ANOVA = analysis of variance; 
Table 3C. Critical appraisal table

\begin{tabular}{|c|c|c|c|c|c|}
\hline Author & Any side effects of treatment & $\begin{array}{c}\text { Null finding } \\
\text { interpretation }\end{array}$ & Important effects overlooked & Comparison with previous literature & Implications for practice \\
\hline Castro et al. 2003 [38] & $\begin{array}{l}\text { Pain, Cardiovascular, Gatrointestinal, Haematological symptoms, Neurotoxicity, Hepatoxicity, } \\
\text { Occular toxicity, Edema } \\
\text { Severe side effects CDDP/epi gel group: } 54.8 \% \text { (34/62), } \\
\text { Placebo gel group: } 28 \% \text { ( } 7 / 25)\end{array}$ & Rejected & $\begin{array}{l}2 \text { patients died- supposed to be } \\
\text { related to treatment with CDDP/epi } \\
\text { gel: } 1 \text { CVA, } 1 \text { fatal haemorrhage }\end{array}$ & Conclusions similar to study by Werner et al. & $\begin{array}{l}\text { CDDP/epi gel is a good option for recurrence, but } \\
\text { demands proper patient selection and skilful use }\end{array}$ \\
\hline Georgiou et al. 2000 [39] & $\begin{array}{l}\text { Group A (thoracic catheter) } \\
\text { Group B (cervical catheter): } \\
\text { nausea and vomiting: A 50\% (8/16);B B 31\% (4/13) } \\
\text { urinary retention: A } 12.5 \%(2 / 16) ; \text { B 0\% } \\
\text { constipation: A A } 2 \%(10) / 62) ; 38 \%(5 / 13) \\
\text { purities: A 31\% (5/16); B 15\% (2/13) }\end{array}$ & Rejected & $\begin{array}{l}\text { More side effects in patients who } \\
\text { received thoracic epidural morphine }\end{array}$ & $\begin{array}{l}\text { Agrees with the literature on the efficacy of epidural } \\
\text { analgesia }\end{array}$ & $\begin{array}{l}\text { In cases of oral analgesia being ineffective epidural } \\
\text { morphine is a good option with cervical being } \\
\text { superior to thoracic. }\end{array}$ \\
\hline Jovic et al. 2008 [40] & $\begin{array}{l}\text { Group A (Ketoprofen) } \\
\text { Group B (Metamizole): } \\
\text { nausea: A 10\% (3/30); B 13.3\%(4/30), bleeding from wounds: A 10\% (3/30); B 10\% (3/30), } \\
\text { haematomas: A 10\% (3/30); B } 6.7 \%(2 / 30) \text {, } \\
\text { infections: A } 10 \%(3 / 30) ; \text { B 3.3\% (1/30). }\end{array}$ & Rejected & None & No prior studies found & $\begin{array}{l}\text { Ketoprofen is an alternative to Metamizole for } \\
\text { reducing pain postoperatively. More research is } \\
\text { needed. }\end{array}$ \\
\hline McNeely et al. 2004 [47] & 10\% (1/10) episode of nausea in PRET patient & Rejected & $\begin{array}{l}\text { Varying period between surgery and } \\
\text { exercise intervention }\end{array}$ & Concurs with previous studies & Exercise is an option post surgery to reduce pain \\
\hline McNeely et al. 2008 [27] & Pain in $3.7 \%(1 / 27)$ patient & Rejected & None & Agrees with McNeely et al. 2004 (pilot study) & $\begin{array}{l}\text { Addition of PRET could be considered in Head and } \\
\text { Neck cancer survivors, but more research with a less } \\
\text { specific group needed }\end{array}$ \\
\hline Pfister et al. 2010 [48] & 27 minor events including: pain, bruising and bleeding & Rejected & None & $\begin{array}{l}\text { Comparable results with similar acupuncture trials on } \\
\text { cancer pain. }\end{array}$ & $\begin{array}{l}\text { As acupuncture has only a few minor side effects, } \\
\text { potential benefit outweighs risk. }\end{array}$ \\
\hline Plantevin et al. 2007 [41] & $\begin{array}{l}\text { MNB with ropivacaine } \\
\text { blood aspiration: A 26.3\% (5/19); } \\
\text { Paraesthesia: A } 31.6 \%(6 / 19) ; \\
\text { No complications in GA group }\end{array}$ & Rejected & $\begin{array}{l}\text { No evaluation of block efficacy to } \\
\text { maintain blinding. } \\
\text { Patients must understand PCA }\end{array}$ & First study to be carried out & $\begin{array}{l}\text { Beneficial for certain types of oropharyngeal } \\
\text { surgery }\end{array}$ \\
\hline Roussier et al. 2006 [42] & $\begin{array}{l}\text { Group A (PCA-Epid) } \\
\text { Group B (PCA-IV): } \\
\text { Nausea: A } 5 \%(1 / 20) ; \text { B 0\%, } \\
\text { Vomiting: A } 5 \%(1 / 20) ; \text { B 4.5\% (1/22), } \\
\text { Pruritus: A 5\% }(1 / 20) ; \text { B 0\%, } \\
\text { Urinary retention: A 0\%; B } 9.1 \% \text { (2/22) }\end{array}$ & Rejected & Patients must understand PCA & Concurs with previous studies & $\begin{array}{l}\text { Dangers of epidural procedure outweigh benefits of } \\
\text { increased pain control }\end{array}$ \\
\hline Saxena et al. 1994 [43] & $\begin{array}{l}\text { Piroxicam group: } 30 \% \text { (6/20) experienced dry mouth } \\
\text { ASA group: } 31.3 \% \text { (5/16) experienced GI symptoms (e.g. nausea, sour eructations, vomiting) }\end{array}$ & Accepted & 4 day follow-up & First study to be carried out & $\begin{array}{l}\text { Piroxicam has less severe side effects and once daily } \\
\text { dosing }\end{array}$ \\
\hline Singhal et al. 2006 [44] & $6.7 \%(2 / 30)$ patients on IV morphine were lethargic & Rejected & None & $\begin{array}{l}\text { First trial of type. } \\
\text { Comparable trials on thoracic surgery yield similar results }\end{array}$ & $\begin{array}{l}\begin{array}{l}\text { Implications limited as epidural risks outweigh } \\
\text { benefits }\end{array} \\
\end{array}$ \\
\hline Werner et al. 2002 [45] & $\begin{array}{l}\text { Group A (CDDP/epi gel) } \\
\text { Group B (Placebo gel): } \\
\text { pain: A 33.3\% (19/57); B 11.4\% (4/35), } \\
\text { tachycardia: A 5.3\% (3/57); B } 0 \%, \\
\text { local cytotoxic effects, } \\
\text { headache: A 5.3\% (3/57); B 0\%, } \\
\text { nausea and vomiting: A 14\% (8/57); B 0\%, hypomagnesemia: A } 5.3 \% \text { (3/57); B 0\%, local cytotoxic } \\
\text { effects (erosion erythema, eschar, necrosis, swelling and ulceration): A } 127 \text { cases B } 34 \text { cases } \\
\text { serious adverse event one in each of 8 patients: } \\
\text { anaemia, allergic reaction, haemorrhage, pallor, } \\
\text { blindness, cardiac arrest (non-fatal), oedema, and swelling. }\end{array}$ & Rejected & $\begin{array}{l}\text { Subjective pain scoring by patients. } \\
(24 / 29) \text { crossed over to receive } \\
\text { active treatment affer dropping out. } \\
\text { Intention to treat maintained }\end{array}$ & Concurs with previous studies & $\begin{array}{l}\text { Can be done as out patient } \\
\text { Useful in palliation and intractable pain }\end{array}$ \\
\hline Wittekindt et al. 2006 [46] & Neck muscle weakness in $20 \%(2 / 10)$ patients in the BtxA high dose group & Rejected & No placebo group & $\begin{array}{l}\text { First study to investigate effect of different doses of BtxA. } \\
\text { Previously reported that use of BtxA leads to pain } \\
\text { reduction after neck dissection surgery. }\end{array}$ & $\begin{array}{l}\text { Low dose BtxA injections are a plausible option to } \\
\text { reduce pain after neck dissection, however more } \\
\text { studies are needed to determine dosage. }\end{array}$ \\
\hline Yagi et al. $1997[\underline{35}]$ & None mentioned & Rejected & $\mathrm{N} / \mathrm{A}$ & $\begin{array}{l}\text { Agrees with literature on efficacy of Fentanyl and } \\
\text { Piroxicam }\end{array}$ & $\begin{array}{l}\text { IV Fentanyl or pre-operative Piroxicam are good } \\
\text { alternatives in the management of head and neck } \\
\text { cancer pain postoperatively. }\end{array}$ \\
\hline
\end{tabular}

$\mathrm{CVA}=$ cerebrovaskular accident; $\mathrm{CDDP} /$ epi gel $=$ intratumoral cisplatin/epinephrine injectable gel; $\mathrm{PCA}=$ patient controlled analgesia; $\mathrm{PRET}=$ progressive resistance exercise training; ASA = acetylsalicylic acid. 